\title{
THE WARS OF FREDERICK THE GREAT
}

Dennis E. Showalter

Longman, New York, 1996

371 pages

maps

ISBN 0582062608 hard cover

ISBN 0582062594 paperback

Price not stated

The study of the wars of Frederick the Great by Dennis E. Showalter is both fascinating and informative. King Frederick II ruled Prussia from 1740 to 1786 . During his reign Prussia was involved in a number of wars (notably the Seven Years War). The reign of Frederick is acknowledged as the era in which Prussia was establish as a first ranking power in Europe. Yet, the Wars of Frederick the Great is more than just a campaign history of Frederick's wars. In this study the author places Frederick's wars, Frederick's reign in Prussia and the art of war and statecraft within the context of the time, which makes this work an important contribution to the study of Military History and power politics in the eighteenth century.

Showalter explains the eighteenth century against the background of the aftermath of the Thirty-Year War and the social, economic and political patterns that stimulated state formation in this era. States saw themselves as power entities existing in an environment were they were in constant interaction with other states, which made diplomacy and war making of prime importance. War, during the Age of Reason (the eighteenth century) was viewed as a rational means of arbitration between states. By concentrating on the diplomatic and military interaction between states, Showalter endeavour to enter into the minds of decision-makers to explain their way of reasoning. One therefore gets to grips with the topic through the perceptions and objectives of the participants.

Showalter surveys the different wars in chronological order and places the military operations and Frederick's policies and ambitions against the broader context. This is a major attribute of the book. Despite the fact that its essentially a chronological survey, it is not merely a list, discussing the one event after the other. As negotiations, treaties, campaigns, marches and battles did not take place in a vacuum, events are elucidated against the background of the time.

Showalter's work reads well and is written in a easy style with annotations at the bottom of the page. Unfortunately Showalter's research was essentially from secondary sources. It is clear from his references and his discussion of the sources that he thoroughly studied material related to the topic. Nonetheless a thorough rework on some of the archives might have made a valuable contribution, since discussions sometimes centre around perceptions in different scholarly works, while primary research could have thrown a new light. 
In the first chapter Showalter essentially introduces and creates an understanding for war in the Age of Reason by discussing and analysing the different scholarly approaches to the topic. In this context examination of the particular structures and military, political, economic as well as societal limitations that shaped eighteenth century warfare is of particular interest. Included in this chapter is a valuable discussion on the rise of Prussia and the establishment of the Prussian military before the accent of Frederick II as well as a short biographical sketch of the young Frederick.

The second and third chapters deal with the Silesian War and the aftermath of the war up to the outbreak of the Seven Years' War. Showalter succeeds in explaining/Frederick's motives and Prussia's position on the stage of European states. It is interesting to see how the young king (not yet "the Great" as Showalter mentions) learns his craft and utilises his opportunities. After the war in the "breathing space" the "next round" is planned and Prussia undergoes a "military evolution". Of particular interest is the discussion on the different arms of service, their equipment, drills and tactical preparations, to train the army and to prepare it for the battlefield. The chapter ends with an explanation of the diplomacy of the day, which gives the reader insight into the complexities that lead to the outbreak of the Seven Years' War in 1756 .

Altogether three of the seven chapters in Showalter's book (chapters four to six) deals with the Seven Years' War. This is a major part of the book and could be regarded as the essence of the topic. Of interest is the author's discussion of Frederick successes during the first year, specifically the Rossbach and Leuthen campaign. This discussion shows good understanding and appreciation of the warfare in the age, during different seasons as well as the effect a classical Frederickian battle had on its enemies. After the success of the first year of the war a period of balance (1758-59) ensued, followed by a very difficult time for Frederick and Prussia (1760-63), during which an exhausted Prussia on the brink of collapse, basically stood against the whole of Europe. Showalter clearly illustrates that although the Seven Years' War was not a total war as we understands it today, Prussia survived by evolving towards "the modern model of the warfare state, with army, economy, and society combined in a symbiosis devoted to establishing and maintaining Prussia as a great power." (p 322) The army took first place in this model, hence a well-founded tax system and sound economy were important prerequisites.

Chapter Seven is a discussion on the last twenty-three years of Frederick's reign with specific reference to the remodelling of the Prussian army and the deterrence value thereof. This chapter provides insight into the mind of the "old king", his realisation that the Seven Years' War was a very "near-run thing" and that for Prussia to hold its own in the "first rank" amongst states, it must recover. Frederick understood Prussia's role in the Europe of his day and accepted military power as an extension of policy.

One impression the reader is left with is that Showalter have excellent insight into the period and his topic. According to him, understanding the wars of Frederick the Great depends on grasping two points. First, at an operational level, deadlock is the normal condition in war. Frederick's way of war was not inherently unique, but his skills as strategist and commander could force a long end game, specifically when surrounded by varied 
enemies. Secondly statesmen and soldiers of the eighteenth century desired balance and understood correlating ends and means, risks and gains, aspirations and possibilities. Balance had to prevent empire, not preserve peace. Frederick did not sought to overthrow the balance in Europe, but he wanted to adjust it in Prussia's favour; adjusting Europe's structure without denying its principles. For this the army was designed to maximise the state's war making potential, while the government, economy and society were placed at the service of the military, tapping the resources without exhausting them.

Showalter clearly shows that Frederick's army was as much a deterrent than a warfighting instrument, its first intention to win victories then to demonstrate the state's readiness and ability to defend its interests. To establish Prussia's deterrent credibility took Frederick more than two decades, but once it was in place, it endured for two decades after Frederick's death. Considerable for a time when war was accepted as a normal consequence of diplomacy. It took the likes of Napoleon to challenge Frederick's legacy.

Perhaps The Wars of Frederick the Great by Dennis E. Showalter's can be viewed as "unfashionable", since it has to do with wars, battles and campaigns. Furthermore it does not focus on enlisted men and peasants, but instead on the experience of monarchs, generals and ministers and their decisions. It emphasis war making and the behaviour of those that waged war. Nonetheless it is a good book and a substantial analysis of political-military interaction during the Age of Reason. It is suggested reading for students of the period. But, since the book also "tells a story" with a lively, authoritative account of great campaigns, victories and defeat on the battlefield it is a narrative general readers will also enjoy.

Cdr Thean Potgieter, Military History Department, Faculty of Military Science, University of Stellenbosch. 


\title{
CONFERENCE NOTICES AND CALL FOR PAPERS
}

\author{
SECOND BILATERAL CONFERENCE
}

\section{DUTCH AND SOUTH AFRICAN HISTORIANS}

\author{
5 - 7 JULY 2000
}

\section{NETHERLAND}

\section{Call for papers}

The second bilateral conference is to be held on 5 - 7 July 2000 at the NIAS, Wassenaar, Netherland. Historians interested in giving a paper should send a brief outline (one A4 page) as soon as possible, (not later than the end of June 1999) to the address below. The broad topics for the conference are:

1. The DEIC period.

2. The European influences on South Africa.

3. The influence of Africa on the Netherlands.

4. Dutch missions and missionaries in South Africa.

For more information contact

PROF H.J. VAN ASWEGEN

DEPARTMENT OF HISTORY

RAND AFRIKAANS UNIVERSITY

\author{
P.O. Box 524 \\ Auckland Park \\ Johannesburg \\ Republic of South Africa \\ 2006 \\ Tel: (011) 489 2004/1 \\ Fax: (011) 4892617 \\ E-mail: hjva@raua.rau.ac.za
}

